\title{
A survey of the terrestrial vertebrates of Faure Island, Shark Bay, Western Australia
}

\author{
Andre Schmitz and Jacqueline D. Richards \\ Australian Wildlife Conservancy, Suite 5, 280 Hay Street, Subiaco, WA 6008 Australia; \\ E-mail: jacqui(mastralianwildlife.org
}

\begin{abstract}
A terrestrial vertebrate survey was conducted on Faure Island in the Shark Bay World Heritage Area in May 2000, and a follow-up survey in February 2002. A single species of mammal, the introduced house mouse, was captured and 22 species of reptile were trapped, collected or sighted by opportunistic searches. There are likely to be additional species not yet collected.
\end{abstract}

Key words: mammals, reptiles

\section{INTRODUCTION}

In May 2000 a terrestrial vertebrate survey was undertaken on Faure Island in the World Heritage Area of Shark Bay, Western Australia. The survey was part of a larger expedition conducted to assess the island's habitats and species diversity for use as the basis for a plan of management and to assist in the development of a reintroduction program for threatened mammals.

The objectives of the trapping survey were to:

- obtain baseline information regarding the terrestrial vertebrate populations present on Faure Island;

- obtain baseline information regarding the distribution and abundance of vertebrates within the different habitats of Faure Island;

- establish permanent transects to monitor changes in abundance over time; and

- determine the suitability of the island as habitat for the reintroduction of a suite of threatened mammal fauna.

An additional survey was undertaken during February 2002, primarily to verify that the threatened Shark Bay Mouse Pseudomys fieldi was not present, prior to a planned reintroduction of this species to the island. Sub-fossil evidence of the species was found on Faure Island by Baynes (2008).

\section{METHODS}

Vertebrates on Faure Island were sampled by (1) trapping using sheffield wire cage traps, (2) trapping using medium and large-sized Elliott traps, (3) pitfall trapping using a centrally positioned 20 litre bucket incorporating seven metres of drift fence (Table 1), and (4) opportunistic sightings made during the course of the survey and searches by raking leaf litter at trap-lines.

The first survey took place over a six day period, 25 May to 1 June 2000. Weather conditions were generally fine and calm with maxima between 20 $25^{\circ} \mathrm{C}$. Some drizzle was encountered on the third day. The second survey took place over a six-day period also, 4-9 February 2002. Temperatures were very hot, with maxima between $35-39^{\circ} \mathrm{C}$.

Sampling sites were determined by the interpretation of vegetation surveys (Keighery and Muir 2008), in conjunction with a colour aerial photograph of the island. Trapping transects were positioned to encompass the suite of habitat types found across the four major landforms found on the island: coastal dunes, sandplain dominated by Acacia shrublands, mangroves and saline flats (Keighery and Muir 2008).

Cage trapping was used predominantly to sample large, relatively broad-ranging vertebrate species. Seventy traps were placed along all existing tracks and fire-breaks which bisected the principal landforms of the island. Eighteen kilometres of track were traversed, with traps placed at every 250

Table 1 Trapping effort for terrestrial vertebrates on Faure Island.

\begin{tabular}{lcc}
\hline Trap Type & $\begin{array}{c}\text { Trap nights } \\
\text { May 2000 }\end{array}$ & $\begin{array}{c}\text { Trap nights } \\
\text { February 2002 }\end{array}$ \\
\hline Pit traps & 360 & 168 \\
Medium Elliott traps & 360 & 648 \\
Large Elliott traps & 360 & 360 \\
Sheffield cage traps & 420 & 0 \\
\hline TOTAL & 1,500 & 1,176 \\
\hline
\end{tabular}




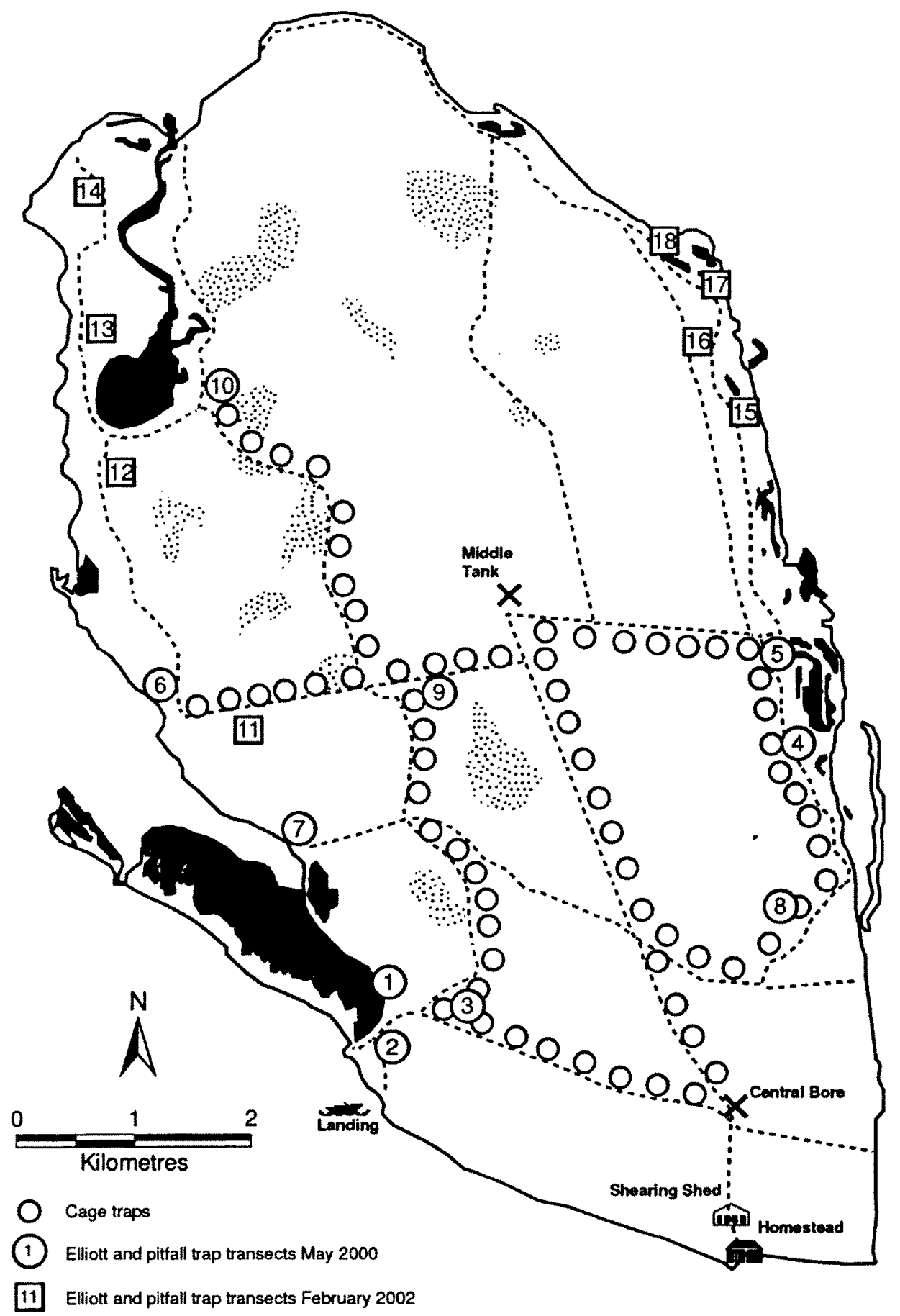

Figure 1 Location of trapping sites on Faure Island.

metres (Figure 1). Traps, covered with Hessian bags, were set a few metres off tracks and under shrubs where possible. 'Universal bait', incorporating peanut butter, rolled oats, and sardines, was used as an attractant and traps were checked early morning and late afternoon. Bait was replenished every two days, or more frequently as required.

Pitfall trapping and Elliott trapping were used to sample the smaller terrestrial vertebrate species. Ten sites were identified from the vegetation surveys (Table 2 and Figure 1) and positioned within discrete habitat types to facilitate sampling
Table 2 Broad habitat descriptions of the trapping sites sampled in May 2000 (1-10) and February $2002(1-18)$.

\begin{tabular}{|c|c|}
\hline Sites & Description \\
\hline $1,7,14,15,16,17,18$ & Coastal Spinifex on white sand dunes \\
\hline $2,6,13$ & Coastal Spinifex on red sand dunes \\
\hline 4,5 & $\begin{array}{l}\text { Low-lying Coastal Spinifex on white } \\
\text { sands below calcrete breakaway }\end{array}$ \\
\hline $8,9,11,12$ & $\begin{array}{l}\text { Acacia Shrubland on undulating } \\
\text { red sandplains }\end{array}$ \\
\hline 3 & Triodia Grassland \\
\hline 10 & Saltbush Flat \\
\hline
\end{tabular}


of the more sedentary species. Transects were used instead of grids because habitat types such as Coastal Dunes and Triodia Grassland were narrow and linear in nature. Six pitfall traps were positioned in a line, $20 \mathrm{~m}$ apart (60 in total). Two Elliott traps (1 large and 1 medium) were paired with each pitfall trap (120 in total). All Elliott traps were positioned within ten metres of pitfall traps in a cleared area beneath vegetation.

Most sites were replicated however the Triodia and Saltbush Flats sites were not. The latter were small, discrete habitats that represented a very small proportion of habitat on Faure Island. Birridas were not sampled during the baseline survey because past experience has shown that this habitat type is relatively unproductive.

During the February 2002 survey pitfall and Elliott trapping adhered to the methodology used in May 2000. An additional eight trapping transects using Elliott traps were established in areas of assumed Shark Bay Mouse habitat concentrating on coastal dunes and fringes, in or adjacent to Spinifex longifolius and mangroves (Figure 1). Cage traps were not used due to the previous lack of mammal and reptile captures in May 2000.

\section{RESULTS}

Vertebrates were trapped on 72 occasions in May 2000 , producing a trap success of $4.8 \%$. Eleven reptile species (and one unidentified Lerista sp.) and one mammal were captured and an additional nine reptile species were identified by opportunistic sampling (Table 3; including two dragons for which no specimens were captured). Two Little Crows Corvus bennetti were captured in cage traps but have not been included in the table.

Ctenotus fallens was the most common vertebrate trapped, followed by House Mice Mus musculus and Morethia lineoocellata (Table 3). The majority of Ctenotus fallens were found in Triodia grassland, coastal Spinifex on red and white sand dunes, and

Table 3 Results of the vertebrate sampling on Faure Island. $\mathrm{P}=$ pitfall trap, $\mathrm{E}=$ Elliott trap, $\mathrm{O}=$ opportunistic, Sites from Table 2 .

\begin{tabular}{|c|c|c|c|c|}
\hline Species & $\begin{array}{c}\text { Collection } \\
\text { method }\end{array}$ & $\begin{array}{l}\text { Captures } \\
\text { May } 2000\end{array}$ & $\begin{array}{l}\text { Captures } \\
\text { Feb } 2002\end{array}$ & Site \\
\hline \multicolumn{5}{|l|}{ SKINKS $(12+1 ?)$} \\
\hline Cryptoblepharus plagiocephalus & $\mathrm{O}$ & - & - & \\
\hline Ctenotus fallens & $\mathrm{P}$ & 24 & 43 & $1,2,3,4,5,6,7,9,11,12,14,15,16,17$ \\
\hline Lerista connivens & $\mathrm{P}$ & 1 & - & 9 \\
\hline Lerista elegans & $\mathrm{P}$ & 5 & - & 1,5 \\
\hline Lerista lineopunctulata & $\mathrm{O}$ & - & - & \\
\hline Lerista macropisthopus & $\mathrm{O}$ & - & - & \\
\hline Lerista micra & $\mathrm{O}$ & - & - & \\
\hline Lerista planiventralis & $\mathrm{P}$ & 1 & 14 & $1,2,3,4,7,10$ \\
\hline Lerista praepedita & $\mathrm{P}$ & 1 & - & 7 \\
\hline Lerista varia & $\mathrm{O}$ & - & - & \\
\hline Lerista sp.? & $\mathrm{P}$ & 2 & - & 1,7 \\
\hline Menetia greyii & $\mathrm{P}$ & 1 & - & 2 \\
\hline Morethia lineoocellata & $P$ & 12 & 3 & $1,3,6,7,9,10$ \\
\hline \multicolumn{5}{|l|}{ GECKOS (5) } \\
\hline Lucasium squarrosum & $\mathrm{P}$ & 1 & - & 10 \\
\hline Gehyra variegata & $\mathrm{P}$ & - & 10 & $1,2,3,4,5,6$ \\
\hline Heteronotia binoei & $\mathrm{P}$ & 3 & - & $1,2,5$ \\
\hline Nephrurus levis & $\mathrm{P}$ & 3 & - & 4,10 \\
\hline Strophurus strophurus & $\mathrm{O}$ & - & - & \\
\hline \multicolumn{5}{|l|}{ DRAGONS (2?) } \\
\hline Ctenophorus reticulatus & $\mathrm{O}$ & - & - & \\
\hline Pogona minor? & $\mathrm{O}$ & - & - & \\
\hline \multicolumn{5}{|l|}{ MONITORS (1) } \\
\hline Varanus gouldii & E & - & 4 & $3,11,13$ \\
\hline \multicolumn{5}{|l|}{ SNAKES (2) } \\
\hline Antaresia stimsoni & $\mathrm{O}$ & & - & \\
\hline Simoselaps littoralis & $\mathrm{P}$ & 2 & - & 4 \\
\hline \multicolumn{5}{|l|}{ MAMMALS (1) } \\
\hline Mus musculus & $\mathrm{P}, \mathrm{E}$ & 16 & 14 & $1,2,3,6,7,11,13,14,15,16,17,18$ \\
\hline TOTALS & $21+3 ?$ & 72 & 88 & \\
\hline
\end{tabular}


Table 4 Total number of vertebrates captured in traps in each habitat sampled in May 2000 and February 2002.

\begin{tabular}{lcc}
\hline Habitat & $\begin{array}{c}\text { May } \\
\mathbf{2 0 0 0}\end{array}$ & $\begin{array}{c}\text { February } \\
\mathbf{2 0 0 2}\end{array}$ \\
\hline Coastal Spinifex on red sand dunes & 22 & 18 \\
Coastal Spinifex on white sand dunes & 10 & 35 \\
Low-lying coastal Spinifex on white & 9 & 16 \\
sands below calcrete breakaway & 9 & 14 \\
Triodia grasslands. & 3 & 5 \\
Acacia shrubland on undulating red & 3 & 0 \\
sandplains & 4 & 88 \\
\hline Saltbush flats & 57 & \\
\hline TOTALS & & \\
\hline
\end{tabular}

low-lying coastal Spinifex, with $94 \%$ of records from these sites. Morethia lineoocellata appeared to favour coastal Spinifex on red and white sand dunes and Triodia grassland, with $80 \%$ of records captured in these habitats. It was not recorded at all in the low-lying coastal Spinifex. Gehyra variegata were found only in areas of coastal Spinifex and Lerista planiventralis were found in areas of coastal Spinifex and a single individual in saltbush flats. House Mice were found predominantly in coastal Spinifex on red and white sand dunes (87\%). No mice were recorded in saltbush flats and only four individuals in Triodia grassland, Acacia shrublands and low-lying coastal Spinifex on white sands below calcrete.

Vertebrates were trapped on 88 occasions in February 2002, producing a trap success of $7.5 \%$. An additional two reptile species Varanus gouldii and Gehyra variegata were trapped for the first time and Ctenotus fallens and Morethia lineoocellata were confirmed as common on the island. Lerista planiventralis were more commonly trapped, while the majority of other reptile species were not trapped.

\section{DISCUSSION}

The vertebrate trapping surveys supported the hypothesis that there were no native mammals surviving on Faure Island. Sub-fossil material confirming the prior existence of native mammals on Faure Island has been found and reported by Baynes (2008). Exotic mammals still present include the House Mouse, Feral Cat Felis catus, Sheep Ovis aries and Goat Capra hircus. The Black Rat Rattus rattus has not been recorded, despite being present on the mainland to the north and south of Shark Bay (Watts 1995).

Baynes (1990) described the mammal fauna of the Shark Bay region, although he did not assess Faure Island as a separate entity, regarding the island as geologically similar to Peron Peninsula. The only native mammal previously recorded from Faure Island was one skull of Bettongia penicillata (Baynes 1990). It is likely that all native mammal species on Faure Island were driven to extinction by predation from feral cats. Other Australian islands on which cats have been implicated in the loss of mammals include Dirk Hartog, Hermite, Trimouille, St Francis and Reevesby Islands (Burbidge and Manly 2002).

Results from the survey confirmed the presence of at least 22 species of reptile extant on the island (Aplin et al. 2008). The gecko Diplodactylus pulcher was not recorded during this survey but was collected from the island in 1989 (Morris et al. 1990). Further trapping may confirm the existence of additional reptile species as it is likely that the island's herpetofauna remains poorly sampled (Aplin et al. 2008). The taxonomic status of particular groups and 'complexes', including the genera Menetia and Morethia is unclear and further revision is required (Aplin et al. 2008).

Over 60 species of reptile have been recorded in the Shark Bay region, of which 24, 30 and 17 species have been found on the larger Dirk Hartog, and smaller Bernier and Dorre Islands, respectively (Storr and Harold 1978; Storr and Harold 1980; Maryan et al. 1984; Morris et al. 1990; Storr and Harold 1990; Cogger 1996; Aplin et al. 2008). Aplin et al. (2008) described the herpetofauna of Faure Island as a subset of that found within the adjacent Peron Region, with the possibility of 'drop out' extinctions and lack of sufficient sampling effort on the island. Alternatively, it is possible that the reptile fauna has suffered from the past impact of feral cats, which are known to consume reptiles in the region (Short et al. 1999). Additional survey work at periods of peak reptile activity (October/ November and March/April) with a greater number of trap nights in each habitat type and additional effort to find more cryptic species such as legless lizards and snakes would be desirable.

The only large reptiles known from the island are Gould's Monitor Varanus gouldii and Stimson's Python Antaresia stimsoni. Neither was active in May 2000, probably due to the cooler temperatures. However, both these reptiles were captured in February 2002 and are common on the island, particularly during warmer weather.

Fewer species were trapped in February 2002, and there was a bias toward particular species such as Lerista planiventralis and Varanus gouldii. This may represent a seasonal difference, with many species less active during the very hot temperatures experienced during the February 2002 survey.

The majority of terrestrial vertebrates were recorded from coastal Spinifex on red and white sand dunes and Triodia grasslands, with few occurrences among the extensive areas of Acacia shrublands that cover much of the island (Keighery 
and Muir 2008). Future management activities to promote the conservation of terrestrial vertebrates on the island will include attempts to eradicate Feral Cats, remove livestock and minimize the risk of fire, particularly amongst the potentially more productive habitat types.

\section{ACKNOWLEDGEMENTS}

This trapping survey was funded by the Australian Wildlife Conservancy (AWC). We are grateful for the assistance of staff from AWC and the WA and SA Museum, particularly John Dell with trapping and the identification of reptiles in the field. We thank Ric How and Mark Cowan for their comments on a previous draft of the manuscript, and Geoff Mauger for his production of maps of Faure Island.

\section{REFERENCES}

Aplin, K., Donnellan, S. and Dell, J. (2008). The herpetofauna of Faure Island, Shark Bay, Western Australia. Records of the Western Australian Museum Supplement 75: 39-53.

Baynes, A. (1990). Mammals (pp. 313-325). In: Berry, P. F., Bradshaw, S.D. and Wilson, B.R. (eds.), Research in Shark Bay Report of the France-Australe Bicentenary Expedition Committee. Western Australian Museum Press, Perth, WA.

Baynes, A. (2008). The original non-volant land mammal fauna of Faure Island, Shark Bay, Western Australia. Records of the Western Australian Museum Supplement 75: 25-31.

Burbidge, A.A. and Manly, B.F. (2002). Mammal extinctions on Australian islands: causes and conservation implications. Journal of Biogeography 29: $465-473$.
Cogger, H.G. (1996). Reptiles and Amphibians of Australia, $6^{\text {th }}$ Edition. Reed Books, Chatswood, NSW.

Keighery, G. and Muir, W. (2008). Vegetation and vascular flora of Faure Island. Records of the Western

- Australian Museum Supplement 75: 11-19.

Maryan, B., Robinson, D. and Browne-Cooper, R. (1984). New records of reptiles on Dirk Hartog Island, Western Australia. Western Australian Naturalist 16: 8-10.

Morris, K.D., Sanders, A. and Harold, G, (1990). Search for Mainland Populations of the Shark Bay Mouse Pseudomys praeconis. Report to World Wildlife Fund (Australia). Department of Conservation and Land Management and Ninox Wildlife Consultants, Perth, WA.

Short, J., Calver, M.C. and Risbey, D.A. (1999). The impact of cats and foxes on the small vertebrate fauna of Heirisson Prong, Western Australia. I. Exploring potential impact using diet analysis. Wildlife Research 26: 621-630.

Storr, G.M. and Harold, G. (1978). Herpetofauna of the Shark Bay region, Western Australia. Records of the Western Australian Museum 6: 449-467.

Storr, G.M. and Harold, G. (1980). Additions to the herpetofauna of the Shark Bay region, Western Australia. Western Australian Naturalist 14: 240.

Storr, G.M. and Harold, G. (1990). Amphibians and reptiles of the Shark Bay area, Western Australia (pp. 279-285). In: Berry, P.F., Bradshaw, S.D. and Wilson, B.R. (eds), Research in Shark Bay Report of the France-Australe Bicentenary Expedition Committee. Western Australian Museum Press, Perth, WA.

Watts, C.H.S. (1995). Black rat Rattus rattus (pp. 659 660). In: Strahan, R. (ed.), The Mammals of Australia. Reed Books, Chatswood, NSW. 